\title{
PENGARUH KUALITAS AIR MINUM DALAM KEMASAN TERHADAP KONSENTRASI OZON
}

\section{The Effect of Drinking Water Quality In Package Against Ozone Concentration}

\author{
Lydia Handayani ${ }^{1 *}$, Sinardi ${ }^{2}$, A.Sry Iryani ${ }^{3}$ \\ 1.2.3Teknik Kimia, Fakultas Teknik, Universitas Fajar \\ Jln. Prof Abdurrahman Basalamah No.101 Makassar, 90231 \\ *Email : handayanilydia31@gmail.com
}

\begin{abstract}
ABSTRAK
Desinfeksipada proses produksi Air Minum Dalam Kemasan merupakan titik kendali kritis yang harus benar-benar diperhatikan. Proses ini harus dilakukan secara baik dan benar, agar kualitas air yang dihasilkan benar-benar steril dan dijamin tidak merugikan kesehatan. Penelitian ini bertujuan untuk mendapatkan pengaruh konsentrasi ozon terhadap kualitas Air Minum dalam Kemasan dan dilakukan pada beberapa merek AMDK yang beredar di Makassar. Sampel yang ada kemudian dilakukan uji kadar ozon dengan ozone test kit sehingga diperoleh konsentrasi ozon dalam ppm. Sampel hasil perlakuan konsentrasi kadar ozon kemudian dilakukan uji bakteri Angka Lempeng Total dan Escherichia Coli. Dari hasil pengujian analisis kadar ozon, diperoleh konsentrasi ozon untuk sampel A 0,2 ppm, sampel B 0,2 ppm, sampel C 0,1 ppm, sampel D 0,1 ppm. Sedangkan jumlah koloni bakteri Escherichia Coli pada masing-masing sampel tidak ditemukan atau tidak terdapat adanya bakteri E.Coli pada semua sampel. Bakteri Angka Lempeng Total pada sampel A, B, C dan D masing-masing : $2 \times 10^{1} ; 1 \times 10^{1} ; 3 \times 10^{1}$ dan $4 \times 10^{1}$ Koloni/ml serta memenuhi persyaratan.
\end{abstract}

Kata Kunci : Desinfeksi, Ozon, AMDK.

\begin{abstract}
Disinfection in the production process of Drinking Water In Packaging is a critical control point that must be properly addressed. This process should be done properly and correctly, so that the quality of the water produced is completely sterile and guaranteed no harm to health. This study aims to obtain the effect of ozone concentration on the quality of drinking water in packaging and conducted on several brands of Drinking Water In Packaging circulating in Makassar. Samples are then tested ozone levels with ozone test kit to obtain the concentration of ozone in ppm. Samples from the treatment of ozone concentration were then tested by bacteria Total Plate Number and Escherichia Coli. From the test result of ozone content analysis, ozone concentration was obtained for sample $A$ $0,2 \mathrm{ppm}$, sample $B$ 0,2 ppm, sample $C$ 0,1 ppm, sample $D 0,1 \mathrm{ppm}$. While the number of colonies of Escherichia coli bacteria in each sample was not found or there were no E.Coli
\end{abstract}


bacteria in all samples. Total Plate Number Bacteria in samples $A, B, C$ and $D$ respectively: $2 \times 10^{1} ; 1 \times 10^{1} ; 3 \times 10^{1}$ and $4 \times 10^{1}$ Colonies $/ \mathrm{ml}$ and meet the requirements.

Keywords: Disinfection, Ozone, AMDK.

\section{PENDAHULUAN}

Desinfeksi pada proses produksi Air Minum Dalam Kemasan (AMDK) merupakan titik kendali kritis (critical control point) yang harus benar-benar diperhatikan. Kegagalan dalam memenuhi batasan titik kritis akan berakibat fatal bagi mutu produk yang pada gilirannya akan berpengaruh terhadap status produk dan keselamatan bagi konsumen yang mengkonsumsinya. Desinfeksi air dapat dilakukan dengan berbagai cara yaitu penggunaan bahan kimia, penggunaan ozon dan penyinaran dengan lampu Ultra Violet.Berdasarkan Surat Keputusan Menteri Perindustrian dan Perdagangan Nomor : 705/MPP/kep/11/2003 diantaranya ditetapkan bahwa proses desinfeksi harus dilakukan dengan cara ozonisasi di dalam tangki pencampur ozon. Konsentrasi ozon untuk proses desinfeksi minimal 0,6 ppm, sedangkan kadar ozon di dalamproduk sesaat setelah pengisian berkisar antara0,1 ppm sampai dengan 0,4 ppm. Selain itu juga ditetapkan bahwa setiap industri AMDK harus memantau kadar ozon di dalam tangki pencampur dan produk. Proses pengolahan AMDK harus melalui proses tahapan baik secara klinis maupun secara hukum, secara higenis klinis biasanya disahkan menurut peraturan pemerintah melalui Departemen Badan Pengawasan Obat dan Makanan Republik Indonesia (BPOM RI) baik dari segi kimia, fisika, mikrobiologi, dan lain-lain ([1]).

Proses sterilisasi harus dilakukan secara baik dan benar, agar kualitas air yang dihasilkan benar-benar steril dan dijamin tidak merugikan kesehatan. Adapun proses ini dilakukan setelah proses perlakuan water treatment dengan menggunakan proses ozonisasi yaitu proses pencampuran gas ozon kedalam air umpan yang telah diproses melalui water treatment system, yang mana ozon ini berfungsi sebagai pembunuh kuman, bakteri serta virus-virus yang kemungkinan masih ada dalam air, serta sebagai pengawet yang food grade yang tidak ada efek samping terhadap tubuh manusia. Proses Ultra Violet Sterilisasi yang bertujuan 
untuk mensterilkan air yang akan masuk ke proses selanjutnya yaitu proses kemasan ([2]).

Proses sterilisasi air dengan ozon ini lebih dikenal dengan teknik ozonisasi, dalam proses pengolahan air minum sendiri terdapat banyak proses karena air sumber yang akan dijadikan air minum mengandung zat besi atau mangan, maka desinfektan dengan ozon akan mengakibatkan terjadinya reaksi oksidasi yang membentuk oksida besi atau oksida mangan yang tidak larut dalam air sehingga warna air menjadi kecoklatan atau terbentuk endapan coklat kehitaman. Untuk mendapatkan air minum dengan kualitas maksinal, maka proses ozonasi biasa dilakukan pada tahapan terakhir dari serangkaian proses pengolahan air minum pada salah satu perusahaan air minum. Ozonisasi merupakan akhir dari pengolahan air minum setelah berbagai zat dalam air seperti logam dan zat lainnya dihilangkan sehingga tidak akan terjadi reaksi kimia antara ozon dengan zat yang lain dengan peranan ozon sebagai desinfektan pembasmi mikroorganisme yang masih berada dalam air. Ozon merupakan gas yang hampir tak berwarna dengan bau yang khas sehingga dapat terdeteksi oleh indera penciuman sampai dengan konsentrasi 0,01 ppm. Konsentrasi maksimum ozon pada ruang terbuka adalah sekitar 0,10 ppm sedangkan konsentrasi1,00 ppm masih dapat dianggap tak berbahaya asal tidak terhirup kedalam saluran pernafasan hingga lebih dari 10 menit. Seperti yang diketahui ozon paling banyak terdapat dalam lapisan stratosfer yang berfungsi sebagai filter dan pelindung bumi dari sinar UV matahari dan sisanya di troposfer yang bersifat sebagai racun dan polutan bagi makhluk hidup di bumi. Gas ozon dapat membahayakan makhluk hidup karena sifatnya yang sangat reaktif yang mudah terdekomposisi menjadi atom $\mathrm{O}_{2}$ dan $\mathrm{O}$, dapat bereaksi dan mengoksidasi dengan mudah zat lain disekitarnya. Sifat ozon yang sangat reaktif ternyata dapat dimanfaatkan sebagai pembersih, penghilang bau, serta sebagai desinfektan yang mampu membunuh semua mikroorganisme seperti bakteri, virus, jamur, dan sebagainya ([3]) . Ozon merupakan bahan pengoksida yang sangat kuat kedua setelah flourin. Penggunaan ozon banyak dipilih dalam pengolahan air karena sifatnya sebagai oksidator kuat yang mampu mengoksidasi berbagai senyawa baik organik maupun anorganik. Ozon terbentuk akibat reaksi 
rekombinan atom-atom oksigen maka ozon sebelum atau setelah bereaksi akan menghasilkan $\mathrm{O}_{2}$ sehingga teknologi ozon sangat ramah lingkungan ([4]).

Kegunaan dalam teknologi, ozonisasi dapat menghilangkan polutan mikroorganisme dan polutan zat organik sekaligus karena hal ini tidak terlepas dari sifat ozon yang dikenal memiliki sifat radikal (mudah bereaksi dengan senyawa disekitarnya) serta memiliki potential oksidasi $2.07 \mathrm{~V}$. Ozon dengan kemampuan oksidasinya dapat membunuh berbagai macam mikoorganisme seperti bakteri Escherichia coli, Salmonella enteriditis, serta berbagai bakteri pathogen lainnya. Selain itu, ozon juga dapat menguraikan berbagai macam senyawa organik beracun yang terkandung dalam air, seperti benzen, atrazin, dioxin dan berbagai zat pewarna organik. Keunggulan lainnya penggunaan ozon adalah pipa, peralatan, dan kemasan akan ikut disanitasi sehingga produk yang dihasilkan akan lebih terjamin selama tidak ada kebocoran di kemasan. Ozon merupakan bahan sanitasi air yang efektif disamping itu juga sangat aman ([5]).

Namun metode ozonisasi memiliki kelemahan diantaranya ozon dapat meracuni manusia bahkan bisa sampai membawa pada kematian apabila terhirup dengan konsentrasi 50 ppm selama kurang lebih 1 jam. Batas kadar konsentrasi penggunaan gas ozon dalam berbagai kegiatan industri adalah 0,1 ppm, sedangkan kadar ozon dalam air hingga 0,05 ppm tidak membahayakan tubuh manusia. Ozon, spesies aktif yang mempunyai sifat radikal ini, memerlukan perhatian khusus dalam penyimpanannya. Kadar 100 persen ozon pada suhu kamar mudah sekali meledak. Ozon akan aman disimpan pada suhu di bawah $1830^{\circ} \mathrm{C}$ dengan kadar ozon dalam campuran ozon dan oksigen dibawah 30 persen. Sekarang ozon kebanyakan disimpan dalam bentuk ozonized-water atau ozonized ice ([6]). Penelitian ini dilakukan untuk mengetahui pengaruh ozon yang ditambahkan pada proses ozonisasi dalam pengolahan AMDK dapat meminimalisir atau bahkan menghentikan pertumbuhan mikroorganisme yang mungkin masih terdapat selama proses pengolahan. Dari penelitian ini diharapkan dapat diketahui apakah konsentrasi ozon dalam air minum benar-benar mempengaruhi bakteri yang terdapat dalam air minum, sebagaimana diketahui hal ini juga berpengaruh terhadap kualitas AMDK. 


\section{METODE PENELITIAN}

Metode penelitian terdiri dari Bahan dan Alat serta Prosedur Kerja

\section{Bahan}

Bahan yang digunakan yaitu Air setelah Proses (untuk sampel MJR), AMDK (Merek A, B, C, D), DPD Total chlorine reagen, Aquadest, Media Violet Red Bile Agar, Media Plate Count Agar, Media Laktose Broth, Media Buffer Peptone Water.

\section{Peralatan}

Alat yang digunakan yaitu Ozon test kit, Pipet Volum $5 \mathrm{ml}$ dan $10 \mathrm{ml}$ Petridisk, Erlenmeyer $250 \mathrm{ml}$, Inkubator, Hot plate, Autoclave, Gelas piala $500 \mathrm{ml}$, Tabung reaksi, Tabung durham, Pembakar spiritus.

\section{Prosedur}

Prosedur penelitian terdiri dari persiapan bahan baku, Analisis Kadar Ozon, Analisis Bakteri Escherichia Coli, dan Analisis Bakteri Angka Lempeng Total.

\section{Ozone DPD Method}

Sampel air setelah proses dan produk AMDK masing-masing $5 \mathrm{ml}$ kemudian dimasukkan dalam tabung ozon tes kit dan ditambahkan reagen DPD Klorin kemudian dihomogenkan dan diamati selama 20 menit. Apabila terjadi perubahan warna dari tidak berwarna ke ungu, maka warna yg timbul kemudian dicocokkan dengan warna pada ozon tes kit disk dimana pada disk ini terdapat konsentrasi $\mathrm{mg} / \mathrm{l}$ atau ppm sesuai dengan warna yang timbul. Metode ini disebut DPD Method.

\section{Analisis Escherichia Coli}

Sebanyak masing-masing $1 \mathrm{ml}$ sampel AMDK dipipet ke dalam cawan petridisk steril kemudian dituangkan 10-15 ml media Violet Red Bile Agar (VRBA), Diratakan dengan cara digoyang sehingga media agar dan sampel homogen serta 
rata bentuknya dalam cawan petri. Didiamkan selama 20 menit agar memadat kemudian dibungkus dengan kertas/koran dan diinkubasi dalam inkubator suhu $38^{\circ} \mathrm{C}$ selama $1 \times 24$ jam. Bila bakteri Escherichia Coli positif, maka akan timbul koloni berwarna ungu tua yang padat dan agak berlendir pada media agar.

\section{Analisis Angka Lempeng Total}

Sebanyak masing-masing $10 \mathrm{ml}$ sampel AMDK dipipet kedalam 100ml media BPW kemudian dihomogenkan. Dari larutan ini dipipet $1 \mathrm{ml}$ ke tabung reaksi yang berisi $10 \mathrm{ml}$ media BPW sebagai pengenceran pertama, $1 \mathrm{ml}$ ke media LB (Uji Pendahuluan 1), dan $1 \mathrm{ml}$ ke petridisk steril. Dari tabung reaksi kemudian dipipet $1 \mathrm{ml}$ ke media LB (Uji Pendahuluan 2), $1 \mathrm{ml}$ ke petridisk steril. Menuang sebanyak 10-15 ml media PCA ke dalam cawan-cawan petridisk yang telah berisi sampel, dihomogekan kemudian dibiarkan memadat sebelum dibungkus kertas dan diinkubasi dalam inkubator suhu $38^{\circ} \mathrm{C}$ selama $1 \times 24$ jam.

\section{HASIL DAN PEMBAHASAN}

\section{Analisis Kuantitatif}

Dari penelitian ini diketahui kadar ozon, koloni bakteri Escherichia Coli dan ALT untuk masing-masing sampel :

Tabel 1 Analisis Kuantitatif sampel AMDK

\begin{tabular}{|c|c|c|c|}
\hline Sampel AMDK & Kadar Ozon & Escherichia Coli & ALT \\
\hline A & $0,2 \mathrm{ppm}$ & $0 \mathrm{koloni} / \mathrm{ml}$ & $2 \times 10^{1} \mathrm{koloni} / \mathrm{ml}$ \\
\hline $\mathrm{B}$ & $0,2 \mathrm{ppm}$ & $0 \mathrm{koloni} / \mathrm{ml}$ & $1 \times 10^{1} \mathrm{koloni} / \mathrm{ml}$ \\
\hline $\mathrm{C}$ & $0,1 \mathrm{ppm}$ & $0 \mathrm{koloni} / \mathrm{ml}$ & $3 \times 10^{1} \mathrm{koloni} / \mathrm{ml}$ \\
\hline $\mathrm{D}$ & $0,1 \mathrm{ppm}$ & $0 \mathrm{koloni} / \mathrm{ml}$ & $4 \times 10^{1} \mathrm{koloni} / \mathrm{ml}$ \\
\hline
\end{tabular}


A kemasan cup $240 \mathrm{ml}$ sebanyak 0,2 ppm : B kemasan cup $240 \mathrm{ml}$ sebanyak 0,2 ppm : C kemasan cup $220 \mathrm{ml}$ sebanyak 0,1 ppm : D kemasan cup sebanyak 0,1 ppm. Dimana kadar ozon dalam produk Air Minum Dalam Kemasan memang berkisar antara 0,1-0,4 ppm berdasarkan Surat Keputusan Menteri Perindustrian dan Perdagangan Nomor : 705/MPP/kep/11/2003.

Di pabrik pengolahan air minum, ozon diproduksi ketika molekul oksigen $\left(\mathrm{O}_{2}\right)$ terdisosiasi oleh sumber energi menjadi atom oksigen dan kemudian bertumbukan dengan molekul oksigen membentuk gas yang tidak stabil yaitu ozon $\left(\mathrm{O}_{3}\right)$, yang digunakan untuk mendisinfeksi air. Kebanyakan pabrik pengolahan air menghasilkan ozon dengan menggunakan listrik arus bolak balik tegangan tinggi (6-20 kilovolt) sepanjang dielectric discharge yang mengandung bantalan gas oksigen. Ozon merupakan disinfektan yang lebih efektif jika dibandingkan dengan khlorin, khloramin, dan bahkan khlorin dioksida.

Kegunaan ozon dalam teknologi ozonisasi adalah dapat menghilangkan polutan mikroorganisme dan polutan zat organik sekaligus karena hal ini tidak terlepas dari sifat ozon yang dikenal memiliki sifat mudah bereaksi dengan senyawa disekitarnya. Ozon dengan kemampuan oksidasinya dapat membunuh berbagai macam mikroorganisme seperti bakteri Escherichia coli, Salmonella enteriditis, serta berbagai bakteri pathogen lainnya. Selain itu, ozon juga dapat menguraikan berbagai macam senyawa organik beracun yang terkandung dalam air, seperti benzen, atrazin, dioxin dan berbagai zat pewarna organik. Keunggulan lainnya penggunaan ozon adalah pipa, peralatan, dan kemasan akan ikut disanitasi sehingga produk yang dihasilkan akan lebih terjamin selama tidak ada kebocoran di kemasan. Ozon merupakan bahan sanitasi air yang efektif disamping sangat aman. 


\section{Hubungan Bakteri Escherichia Coli terhadap Konsentrasi Ozon}

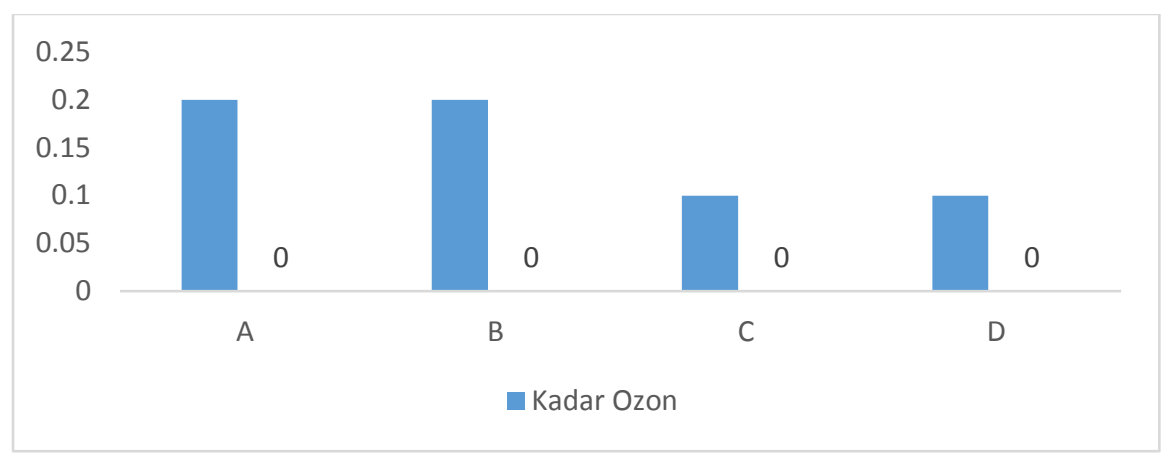

Gambar 1 Hubungan Bakteri Escherichia Coli Terhadap Konsentrasi Ozon

Dari Gambar 1 dapat dilihat hasil analisis mikrobiologi pada masing-masing sampel AMDK memiliki hasil yang baik dimana tidak terdapat koloni bakteri Escherichia Coli dalam keempat sampel yang diuji tersebut, hasil ini telah memenuhi persyaratan berdasarkan SNI 01-3553-2006 dan PerMenKes Nomor 492 Tahun 2010.

\section{Hubungan Bakteri ALT terhadap Konsentrasi Ozon}

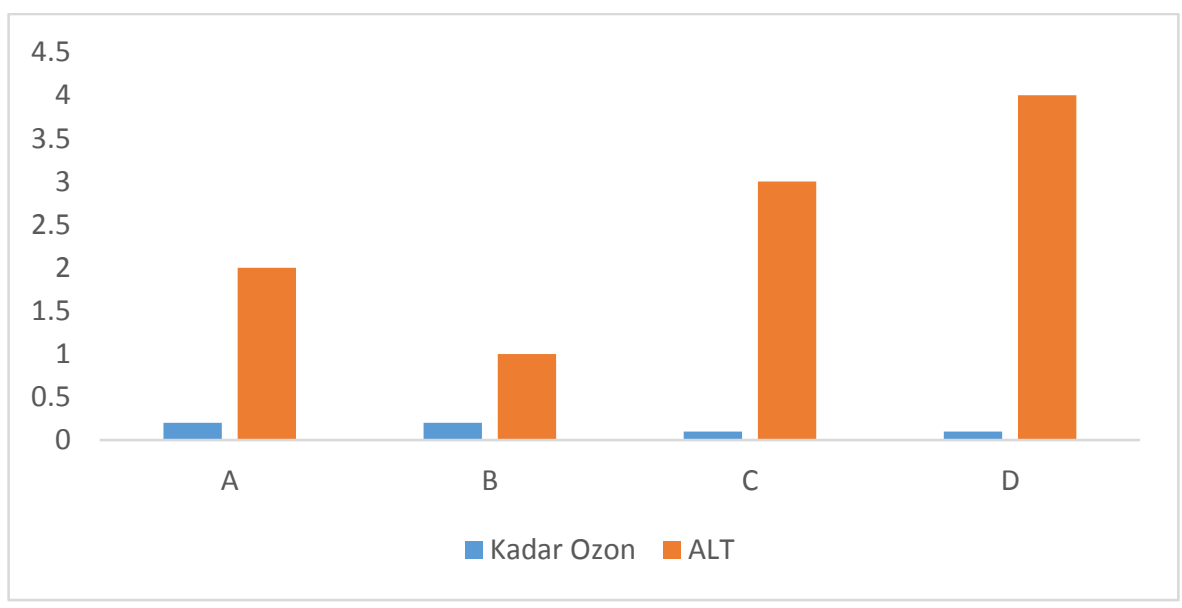

Gambar 2 Pengaruh Bakteri ALT Terhadap Konsentrasi Ozon 
Dari Gambar 2, koloni bakteri Angka Lempeng Total diperoleh hasil sebagai berikut :A kemasan cup $240 \mathrm{ml}$ sebanyak 2 Koloni/ml; B kemasan cup $240 \mathrm{ml}$ sebanyak $1 \mathrm{Koloni} / \mathrm{ml}$; C kemasan cup $220 \mathrm{ml}$ sebanyak $3 \mathrm{Koloni} / \mathrm{ml}$; Dkemasan cup $220 \mathrm{ml}$ sebanyak $4 \mathrm{Koloni} / \mathrm{ml}$. Total bakteri Angka Lempeng Total yang tumbuh pada media PCA ini tidak mencapai 25-250 koloni, Jumlah tersebut mempengaruhi perhitungan ALT koloni. Koloni total yang ditemukan pada penelitian ini kurang dari 25 koloni sehingga ALT koloni yang dihitung adalah dari koloni yang ada pada tingkat pengenceran terendah yaitu $10^{-1}$.

Koloni total adalah koloni yang terdapat dalam petridisk setelah dilakukan dua kali pengenceran. Dan faktor pengenceran diambil dari pengenceran yang digunakan dalam penelitian. Sehingga diperoleh hasil bakteri ALT pada sampel A, $\mathrm{B}, \mathrm{C}$, dan D masing-masing : $2 \times 10^{1} ; 1 \times 10^{1} ; 3 \times 10^{1}$ dan $4 \times 10^{1} \mathrm{Kol} / \mathrm{ml}$.

Dengan kata lain bakteri Angka Lempeng Total memenuhi standar yang digunakan yakni berdasarkan SNI 01-3553-2006 dimana jumlah koloni maksimal $1,0 \times 10^{2} \mathrm{Koloni} / \mathrm{ml}$. Uji duga bakteri ALT pada media Laktose Broth juga negatif karena media tidak menjadi keruh dan tabung durham dalam media tidak terdapat adanya gelembung udara.

\section{KESIMPULAN}

Dari hasil penelitian maka dapat disimpulkan bahwa :

1. Pengaruh kualitas AMDK terhadap proses ozonisasi berpengaruh pada kualitas air tersebut dikarenakan ozon yang bersifat sangat reaktif dapat dimanfaatkan sebagai pembersih, penghilang bau, serta sebagai desinfektan yang mampu membunuh atau meminimalisir mikroorganisme seperti bakteri.

2. Dengan konsentrasi ozon yang lebih besar yakni 0,2 ppm memiliki jumlah koloni bakteri ALT yang lebih sedikit yaitu untuk sampel A sebanyak $2 \times 10^{1}$ $\mathrm{Kol} / \mathrm{ml}$ dan $\mathrm{B}$ sebanyak $1 \times 10^{1} \mathrm{Kol} / \mathrm{ml}$ dibandingkan dengan konsentrasi ozon 
0,1 ppm untuk sampel C sebanyak $3 \times 10^{1} \mathrm{Kol} / \mathrm{ml}$ dan $\mathrm{D}$ sebanyak $4 \times 10^{1}$ $\mathrm{Kol} / \mathrm{ml}$, dan juga dari semua sampel tidak terdapat bakteri Escherichia Coli.

\section{DAFTAR PUSTAKA}

Agustini, Sry. 2011. Jurnal Pengaruh Konsentrasi Ozon Terhadap Cemaran Mikroba pada Air Minum Dalam Kemasan. Balai Riset dan Standardisasi Industri Palembang, Balai Besar Industri Agro Bogor. Vol. 22 No. 1: 44-51.

Badan Pengawasan Obat dan Makanan. 2003. Mutu Pangan. Jakarta: Direktorat Survei dan Penyuluhan Keamanan Pangan. Deputi III-BPOM.

Badan Standardisasi Nasional. 2006. SNI 01-3553-2006. Standar Nasional Indonesia Air Minum Dalam Kemasan. Jakarta: Badan Standardisasi Nasional.

Departemen Perindustrian dan Perdagangan. 2003. Keputusan Menteri Perindustriandan Perdagangan Nomor : 705/MPP/kep/11/2003. Jakarta : Departemen Perindustrian dan Perdagangan.

Entjang, I. 2003. Mikrobiologi dan Parasitologi untuk Akademi Keperawatan dan Sekolah Tenaga Kesehatan yang Sederajat. Bandung

Perturan Menteri Kesehatan Republik Indonesia Nomor 492/ MENKES/ PER/ IV/ 2010 Tentang Persyaratan Kualitas Air Minum. Menteri Kesehatan RI.

Said. Nusa. I. 2007. Desinfeksin untuk pengolahan air minum. 15-25. Jakarta. Diakses tanggal 10 April 2017

UD, Rusdi. 2002. Bionatura. Jurnal Universitas Padjajaran, Vol. 4 No. 2, Juli 2002, Hal 96-107.

USEPA. 1999. Ozone Disinfection, Waste Water Technology fact Sheet.

WS, Supriadi. 2015. Pengolahan Air Minum. Laporan Kerja Praktek. PT Anugerah Tirta Somba Opu.

Wulansari. Ria. 2012. Sinergi teknologi ozon dan sinar uv dalam penyediaan air minum sebagai terobosan dalam pencegahan infeksi diare di Indonesia. Skripsi S1. Universitas Indonesia. Diakses tanggal 10 April 2017. 